\section{'Dawn Delight': An Elite Micropropagated Female Papaya Line with Parthenocarpic Fruit Setting and Extended Shelf Life}

\author{
Pious Thomas \\ Thomas Biotech \& Cytobacts Centre for Biosciences (TBCCB), Amruthahalli, \\ Bengaluru, India, 560092
}

Additional index words. Carica papaya, hardening, keeping quality, micropropagation, plant tissue culture, seedless fruits

'Dawn Delight' is a unique female line of papaya with parthenocarpic fruit-setting capability independent of pollination, generally giving seedless fruits, thus saving on the male plant population needed as pollinizers. Propagated exclusively through tissue culture, 'Dawn Delight' gives relatively dwarf trees suitable for high-density planting. Field plants commence flowering in 3-4 months at $30-60 \mathrm{~cm}$ from soil level giving the first harvest in 6-8 months. 'Dawn Delight' is suitable for open field cultivation, yielding 60-100 fruits per tree in 12 months under ideal field conditions. Fruits weigh about 1 $\mathrm{kg}$, roundish to ovoid-oblong with 11-16-mm thick orange-red flesh and $12-14{ }^{\circ}$ Brix TSS. Typically seedless, fruits show slow ripening with firm flesh offering 8-12-d shelf life. Nearby pollinizer sources could impart larger seed-bearing fruits. Fruits are ideal for table purposes and for processing. The hallmark features of 'Dawn Delight' tissue culture papaya include stable female sex form, prolific bearing, medium-sized roundish to ovoidoblong fruits, slow ripening, generally seedless fruits, orange-red flesh, and extended keeping quality.

\section{Origin}

Papaya (Carica papaya L.) is a treasured fruit crop with high nutritive values being a rich source of vitamins, minerals, and carbohydrates. It is also valued as a vegetable and

Received for publication 17 June 2021. Accepted for publication 19 Aug. 2021.

Published online 30 September 2021.

I gratefully acknowledge the funding support for the development of micropropagation technology by Biotechnology Industry Research Assistance Council (BIRAC) through the Biotech Ignition Grant under the project: "Feasibility of longterm micropropagation of papaya and the prospects of commercial level scaling up." I acknowledge the images shared by the farmers/ growers. I thank T.P. Rajendran and K.K. Subramani for the critical reading of the paper.

P.T. is the corresponding author. E-mail: pioust@ gmail.com or thomasbiotech.opc@gmail.com.

This is an open access article distributed under the CC BY-NC-ND license (https://creativecommons. org/licenses/by-nc-nd/4.0/). for its medicinal properties. Papaya forms a common breakfast fruit where the appearance of the cut fruit, its sweetness, flesh texture to hold on to the fork/toothpick, and retention of freshness for extended periods are important features. 'Dawn Delight' is an elite female papaya line with medium-sized fruits of orange-red flesh and possessing good quality attributes. It confirms the concept that gynoecious sex type in papaya constitutes a more stable form deviating from the earlier practice of preferentially micropropagating hermaphrodite types (Fitch et al., 2005; Navarro et al., 2017). 'Dawn Delight' was selected from the segregating population of $F_{1}$ papaya 'Red Lady', a widely grown gynodioecious hybrid involving a mixture of female and hermaphrodite plants.

Over 100 seeds were gathered from market-derived scanty seed-bearing medium-size, apparently pistillate, roundish fruits sold as 'Red Lady'. In vitro cultures were initiated from 80 seedling shoot tips (Thomas et al., 2019) and a part of seedling tissues were used for molecular marker-based sex determination (Deputy et al., 2002). Among the identified female lines, 42 established healthy cultures were multiplied individually and a part of these stocks were progressed to hardening and preliminary field evaluation at Bengaluru, India. Based on desired plant and fruit characteristics, five lines were progressed to the second field evaluation with a parallel in vitro multiplication. One elite selection with dwarf plant stature, early flowering, conformity to female sex form, parthenocarpic fruit setting potential, and other desired fruit characteristics was identified and named 'Dawn Delight' (DD01). This line is being maintained in vitro, multiplied through commercial micropropagation technology, and made available to growers.

\section{Description}

'Dawn Delight' papaya gives medium to small size fruits (depending on the stage of crop) suitable for home use and export market with good fruit quality and extended shelf life of about 8-12 d depending on the stage of harvest. A robust micropropagation technology has been developed for 'Dawn Delight' papaya, which involves multiple shoot induction in the proliferation medium, rooting initiation in a rhizogenesis medium, ex vitro primary hardening, and final secondary hardening (Fig. 1). The protocol is covered by the Indian patent application at Chennai, India (No. 202041037562: "Tissue culture-based method of propagation of Carica papaya plant"). The hardened plants are maintained in insect-proof polyhouse with frequent inspection to guard against viral infections and any somaclonal variations/mutations. For field establishment, tissue-cultured (TC) plants of $15-20-\mathrm{cm}$ tall with $6-8$ green leaves are used. Spacing of $2 \times 2-\mathrm{m}$ is recommended to accommodate $\approx 2500$ plants $/$ ha.

Flowering commences within 60-75 d of field planting under full sunlit conditions at $30-60 \mathrm{~cm}$ from ground level comprising of only female flowers. When grown as a mixed/ intercrop, plants in partial shade tend to grow taller, displaying delayed flowering by $2-4$ weeks. Immature fruits generally bear long peduncle, occasionally branched type, allowing sufficient space for proper fruit development (Fig. 2). Fruits show enlargement for about 3 months followed by maturation. Emergence of 3-5 orange streaks toward the fruit distal end indicates ideal harvest stage. First harvest is obtained by about 4 months after flowering or 6-8 months after field planting. Flowering and fruiting appear almost continuous with about $60-100$ fruits within the first 12 months, but sometimes in flushes of 20-40 fruits with 3-6 cycles in 12-15 months.

Fruits are generally seedless, medium-sized, weighing $1.00 \pm 0.25 \mathrm{~kg}$, but sometimes larger fruits of $>2.0 \mathrm{~kg}$ appear. Fruit size stabilizes to the desirable medium size $(600-1000 \mathrm{~g})$ thereafter. Older plants (12-18 months) may have smaller fruits (400-600 g), a market preferred size. As a general description, fruits weigh about 500-800 g, 12-15-cm long, $10-12-\mathrm{cm}$ wide, and $25-30 \mathrm{~cm}$ in circumference. Fruits are generally seedless in a pure crop or in isolation, which is a major contributor to the longer shelf life. Seedless fruits show thinner flesh (12-16 $\mathrm{mm})$ and slow ripening (8-12 d) compared with seeded fruits. Fruit skin appears orange-yellow (\# N25C/N25D under yellow-red range of Royal Horticultural Society Color charts edition V) and flesh turns orange-red (RHS \# N30C/N30D) at full ripening. Being a fully fertile female line, seed development can occur in mixed populations or with pollen sources nearby. Seeded fruits generally appear larger like 'Red Lady' fruits with thicker flesh $(15-20 \mathrm{~mm})$ and faster ripening (6-8 d). The firm texture of seedless fruits of 'Dawn Delight' together with the undisturbed inner surface (unlike the disturbed surface with seed clearing) has captured a new clientele for papaya, which do not normally relish conventional soft flesh types. 'Dawn Delight' fruits exhibited extended keeping quality of about $10 \mathrm{~d}$ in relation to the other varieties compared, namely Solo, Ice Berry, Green Berry, Arka Surya or Arka Prabhath, all of which displayed fast flesh softening upon ripening or following fruit cutting.

A comparison of 100 tissue culture-produced 'Dawn Delight' plants with 100 seedlings of 'Red Lady' maintaining an isolation 


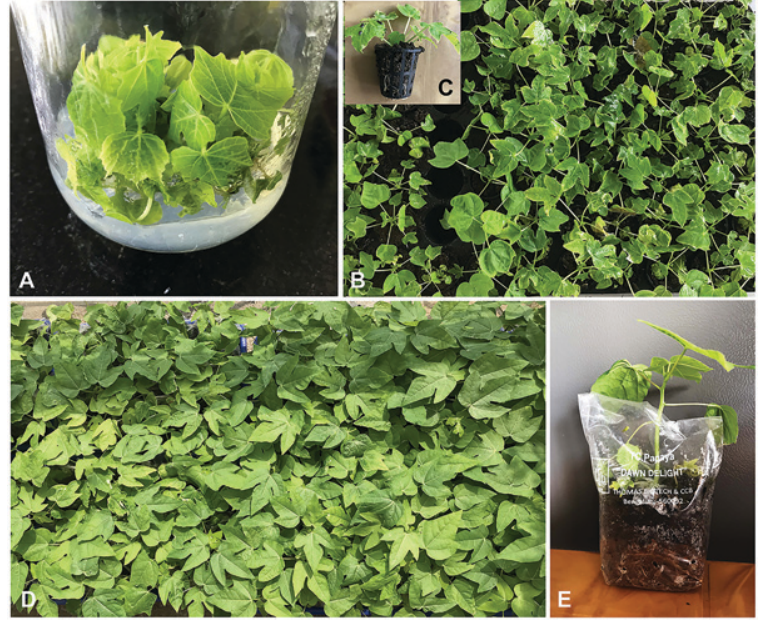

Fig. 1. Steps in micropropagation of 'Dawn Delight', (A) Proliferating in vitro culture. (B) Primary hardened plants in protray net pots. (C) Rooted plant in net pot. (D) Secondary hardened plants. (E) Single hardened plant.

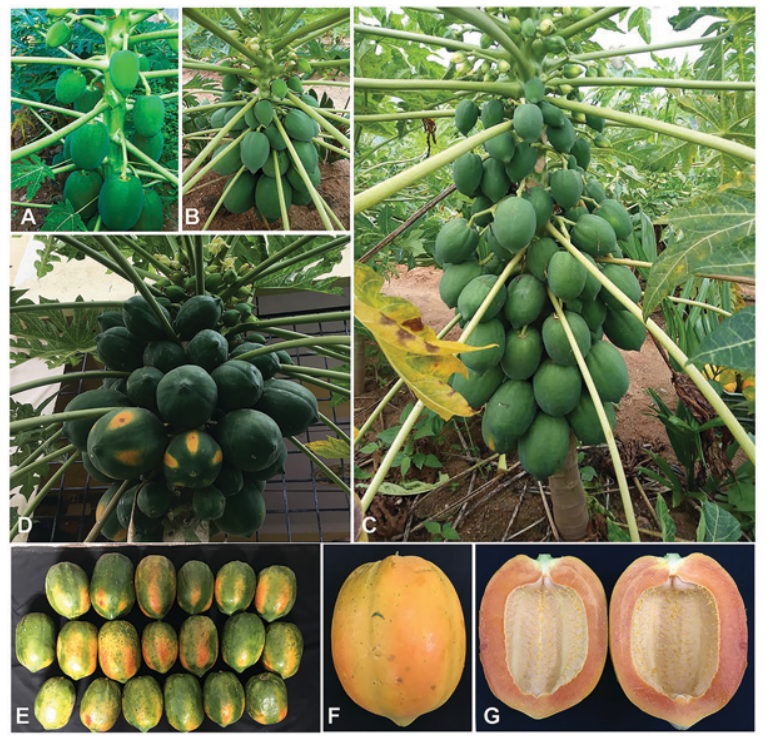

Fig. 2. Field performance of 'Dawn Delight' and fruit characteristics. (A) Five-month-old bearing plant with long peduncle. (B) Six-month-old plant showing dwarf bearing. (C) Seven-month-old plant in full bearing. (D) Fifteen-month-old plant. (E) Fruits of 700-800 g from 8-month-old trees. (F) Ripe fruit 10 $\mathrm{d}$ after harvest. (G). Cut seedless fruit with firm orange-red flesh.

distance of about $100 \mathrm{~m}$, showed similar field establishment $(90 \%$ to $100 \%)$. 'Dawn Delight' had all female plants, dwarf size, and more uniform flowering with onset by $8-10$ weeks, and all plants blossoming by 12-16 weeks. Fruit setting commenced $30-60 \mathrm{~cm}$ from ground level and the first harvest occurred by 6-7 months. Conversely, 'Red Lady' displayed more variation in plant height. Flowering appeared staggered with about $25 \%$ to $40 \%$ plants blooming by 10 weeks and about 16-24 weeks to reach $90 \%$ population. 'Red Lady' plants segregated as female and hermaphrodite/bisexual types, yielding a mixture of small to large round fruits of $1-3 \mathrm{~kg}$ in female plants, and large oblong fruits of $\geq 2 \mathrm{~kg}$ in hermaphrodites. The fruits of 'Red Lady' were highly seeded with thicker red flesh. Round fruit-bearing female plants occasionally showed smaller seedless fruits that were similar to 'Dawn Delight'. On the other hand, 'Dawn Delight' appeared highly uniform with all plants and fruits similar. Being derived from an elite single plant, 'Dawn Delight' matched the total yields of 'Red Lady' with the advantages of one fruit type.

'Dawn Delight' plants grown in farmers' field in different parts of India showed dwarf stature, continuous bearing, improved yields, and better fruit quality with consistent performance. Growing 'Dawn Delight' papaya replaced the pollinizer population requirement of dioecious types giving better net returns. 'Dawn Delight' has shown field tolerance to viral diseases particularly Papaya Ring Spot Virus when the infection occurred after the onset of fruiting.

\section{Uses}

'Dawn Delight' is a good choice for table use. Being a selection from the segregating population of 'Red Lady', 'Dawn Delight' maintains the good qualities of 'Red Lady', with the added benefits of allfemale plants in the field, uniformity with regard to field stand, dwarf stature, early flowering, single fruit type, and matching or higher yields. With firm flesh, 'Dawn Delight' fruits are suitable for canning and dehydration, and for export market. It is also ideal as a vegetable for raw papaya salad and culinary purposes.

\section{Availability}

'Dawn Delight' was released to the farmers for cultivation during 2019. This line is to be registered with the Protection of Plant Varieties and Farmers' Rights Authority (PPVFA), Ministry of Agriculture, Government of India. Technology for micropropagation of this papaya variety is currently under patenting. Fully hardened 'Dawn Delight' plants are now available to growers within India. As for international market, rooted plantlets can be supplied to interested production agencies for further hardening and distribution. Licensing of the protocol for micropropagation of papaya is envisaged for overseas partners.

\section{Literature Cited}

Deputy, J.C., R. Ming, H. Ma, Z. Liu, M.M.M. Fitch, M. Wang, R. Manshardt, and J.I. Stiles. 2002. Molecular markers for sex determination in papaya (Carica papaya L.). Theor. Appl. Genet. 106:107-111, https://doi.org/10.1007/ s00122-002-0995-0.

Fitch, M.M.M., P.H. Moore, T.C.W. Leong, L.A.Y. Akashi, A.K.F. Yeh, S.A. White, A.S Dela-Cruz, L.T. Santo, S.A. Ferreira, and L.J. Poland. 2005. Clonally propagated and seedderived papaya orchards: I. Plant production and field growth. HortScience 40:1283-1290, https://doi.org/10.21273/HORTSCI.40.5.1283.

Navarro, L.C., V. Pétiard, S. Tanksley, A. Casa, B. Moreno, S. Quiroga, E. Espinosa, and J. Fenyvesi. 2017. Papaya (Carica papaya L.) micropropagation and breeding. Acta Hort. 1250:165172, https://doi.org/10.17660/ActaHortic.2019. 1250.23.

Thomas, P., M. Agrawal, and C.B. Bharathkumar. 2019. Diverse cellular colonizing endophytic bacteria in field shoots and in vitro cultured papaya with physiological and functional implications. Physiol. Plant. 166:729-747, https:// doi.org/10.1111/ppl.12825. 